\title{
Contrasting mathematical phenomena and concepts in ethnomathematics through etic and emic approaches: A study of dhikr jahar practices in tariqa qodiriyah naqsyabandiyah ma'had Suryalaya
}

\author{
Eko Yulianto ${ }^{1}$, Wahyudin ${ }^{2}$, Ahmad Tafsir ${ }^{3}$, Sufyani Prabawanto ${ }^{2}$ \\ ${ }^{1}$ Universitas Siliwangi, Indonesia \\ ${ }^{2}$ Universitas Pendidikan Indonesia \\ ${ }^{3}$ Universitas Islam Negeri Sunan Gunung Djati Bandung, Indonesia \\ $\triangle$ ekoyulianto@unsil.ac.id *
}

Article Information

Submitted May 01, 2021

Revised May 17, 2021

Accepted May 29, 2021

\author{
Keywords \\ Dhikr Jahar; \\ Ethnomathematics; \\ Emic-Etic; \\ Mathematical Phenomena and \\ Concepts; \\ Sufism; \\ Tariqa \\ Naqsyabandiyah (TQN).
}

\begin{abstract}
Ethno-mathematical research trends pioneered by D'Ambrosio are on the rise, especially in Indonesia as a nation with high cultural diversity which has a lot of potential researches to be explored. This paper has two major objectives, first to explore the importance of the role of mathematics in the practice of Dhikr Jahar in Tariqa Qodiriyyah Naqsyabandiyyah and second to contrast the differences between mathematical phenomena and mathematical concepts in ethnomathematics research. Attempts to contrast the mathematical phenomena and mathematical concepts in ethnomathematics was expected to provide a sharper highlight in the writing of ethnomathematics research. This research used qualitative methods with two approaches, namely ethnography and phenomenology. The locations of the research are at Pondok Pesantren SuryalayaSirnarasa and Padepokan Talangraga Tasikmalaya with observations for 9 months in the first stage and then 6 months in the second stage. The number of respondents interviewed in this research were 48 people. Data processing was performed using the Nvivo 12 Plus. The results showed that there are many mathematical phenomena in the practice of Dhikr Jahar Ikhwan TQN. In carrying out the practice of dhikr, the Ikhwan used a mathematical concept with two events, fingers and prayer beads aids. The concept of counting in dhikr was used strictly by the Ikhwan. They believe that numbers have an important role in the quantity of dhikr. Contrasting mathematical phenomena and mathematical concepts can be done with an emic and etic approach and is expected to become an alternative style in ethnomathematics research.
\end{abstract}

\section{INTRODUCTION}

The relationship between science and religion (Islam) as two things without a dichotomy has been explained by many researchers (Kamali et al., 2016; Kurniawan \& Tijani, 2017; Masood, 2009). Even the records of the contribution of knowledge from Muslim scholars in algebra, number theory and trigonometry have greatly contributed to current knowledge (Halal et al., 2014) included in astronomy (Rozak, 2015). At present, investigations of mathematical phenomena in the Quran have been carried out by many researchers (Abdussakir, 2014; Awan, 2009; Halal et al., 2014), regression modeling of verbs in the Quran (El Mouatasim, 2018), even the efforts to prove the Quran's instructions about the State of Saba as relics of the prophet Solomon (Basya, 2009; Basya, 2015). Research investigations into how mathematics is strictly used in the practice of dhikr have also been carried out since 2018 and reported in 2020 (Yulianto et al., 2020). concepts in ethnomathematics through etic and emic approaches: A study of dhikr jahar practices in tariqa qodiriyah naqsyabandiyah ma'had Suryalaya. Al-Jabar: Jurnal Pendidikan Matematika, 12(1), 193-218. 
In Islamic teachings the law of dhikr (remembering the Creator) is mandatory based on the orders of Allah SWT. in the Quran (Ta'jul Arifin, 1998). The concept of dhikr which was commanded by Allah SWT. based on the Quran [33: 41] is to do dhikr as much as possible. The concept of 'as much as possible' requires a mathematical explanation so that in its implementation it meets the demands of the science of dhikr. In mathematics, the concept of as much as possible can be interpreted as infinite $(\infty)$, meaning that every second humans are obliged to remember their creator.

Islamic teachings that teach dhikr with a special method is Tariqa (in Arabic: Thoriqoh). Authors have concerned on the research in Tariqa Qodiriyyah Naqsyabandiyyah (TQN) in a long time. Apart from the large number of congregations, the location of the TQN center is also relatively close to the researchers. Recitation in TQN is taught through the talqin process by a Murshid to someone who intends to learn the science of dhikr. Talqin is the teaching of dhikr by Murshid to Ikhwan (disciple) about the correct procedure (guide) of practicing dhikr according to Tariqa science (Basri et al., 2014). Syekh Muhammad Abdul Gaos Saefulloh Maslul explained that "tukang tembok ada ilmunya, tanpa ilmunya adukan semen tidak akan nempel, menjahit ada ilmunya, apalagi zikir tentu harus dengan ilmunya supaya sampai kepada Alloh Swt. [A bricklayer has knowledge, without the knowledge the mortar will not stick, sewing also has knowledge, moreover dhikr must be with the knowledge in order to reach Allah SWT]'. It's described that a bricklayer has the knowledge, without knowledge the mortar will not stick, sewing also has the knowledge, moreover dhikr of course must be with the knowledge in order to reach Allah SWT. Syekh Muhammad Abdul Gaos Saefulloh Maslul explained that in a Tariqa, Talqin is a signaling gate for someone to enter the Tariqa Qodiriyyah Naqsyabandiyyah (Soleha, 2015). There are two dhikr that are done to the Ikhwan of TQN, namely Dhikr Jahar (obviously) and Dhikr Khofi (unspoken). In this discussion, authors will expose more mathematical phenomena in the practice of Dhikr Jahar than Dhikr Khofi.

Syekh Ahmad Shohibulwafa Tajul 'Arifin in the book Uquudul Jumaan (Ta'jul Arifin,

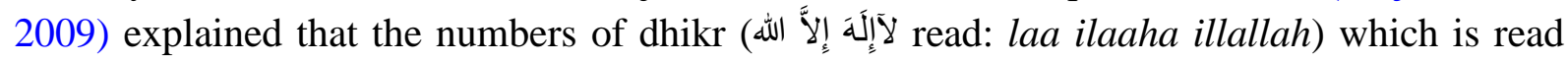
after each prayer, provided that it is not less than 165 times, more is better and ends with an odd number. Mathematically the numbers of dhikr can be written as $\{n \geq 165 \mid n$ is odd $\}$ or $\{n \geq 165 \mid n=2 k+1, \forall k \in N\}$, if someone is busy, they can read it three times but must be replaced (Qodho) in spare time. In the previous article (Yulianto et al., 2020), authors have explained two mathematical phenomena, that the grammatical value of 'laa ilaaha illallah' is 165 .

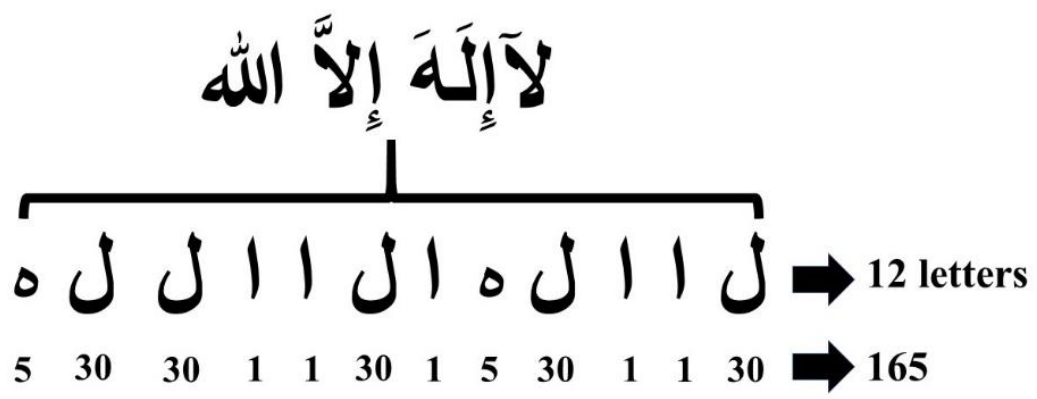

Figure 1. Grammatical Value of 'Laa Ilaaha Illallah' 
The grammatical value is calculated based on the standard guidelines for mathematical calculations explained in the Aljumal book.

Table 1. Arabic Alphabet \& The Grammatical Values

\begin{tabular}{|c|c|c|c|c|c|c|c|c|c|c|c|c|c|c|}
\hline $\begin{array}{l}\text { Arabic Letters } \\
\text { Sequence } \\
\text { Number }\end{array}$ & 1 & 2 & 3 & 4 & 5 & 6 & 7 & 8 & 9 & 10 & 11 & 12 & 13 & 14 \\
\hline Arabic font & 1 & ب ب & ج & 2 & $ه$ & 9 & j & $\tau$ & $b$ & ي & ك & J & 5 & ن \\
\hline Latin & alif & $\mathrm{ba}$ & jim & dal & ha' & waw & $\mathrm{za}$ & ha & tho & ya & kaf & lam & $\operatorname{mim}$ & nun \\
\hline $\begin{array}{c}\text { Grammatical } \\
\text { Values }\end{array}$ & 1 & 2 & 3 & 4 & 5 & 6 & 7 & 8 & 9 & 10 & 20 & 30 & 40 & 50 \\
\hline $\begin{array}{l}\text { Arabic Letters } \\
\text { Sequence } \\
\text { Number }\end{array}$ & 15 & 16 & 17 & 18 & 19 & 20 & 21 & 22 & 23 & 24 & 25 & 26 & 27 & 28 \\
\hline Arabic font & س س & $\varepsilon$ & ف & ص & ق & $\mu$ & ش & $ت$ & $\dot{H}$ & $\dot{\tau}$ & $\dot{j}$ & ض ض & ظ & $\dot{\varepsilon}$ \\
\hline Latin & $\sin$ & ain & $\mathrm{fa}$ & shod & qof & ro & syin & ta & tsa & kho & dzal & dhod & zho & ghoin \\
\hline $\begin{array}{c}\text { Grammatical } \\
\text { Values }\end{array}$ & 60 & 70 & 80 & 90 & 100 & 200 & 300 & 400 & 500 & 600 & 700 & 800 & 900 & 1000 \\
\hline
\end{tabular}

Source: (Al-Khalil bin Ahmad Al-Farahidi, 1985; Manshur, 1925)

Then if the number of letters in the word of 'laa ilaaha illallah' is also the result of the sum of the number $1+6+5=12$. Mathematically, author saw a phenomenon other than numbers 1,6 , and 5 . If it is operated with multiplication operator, it become

$$
1 \times 6 \times 5=30
$$

The number 30 in Islam shows the number of $J u z$ (section of the Quran). Notice how special the odd number 165 is. Another odd feature arises when we play the sum of the squares of the first 5 odd numbers (these 5 represent the Salat as previously assumed), $1^{2}+$ $3^{2}+5^{2}+7^{2}+9^{2}$

$$
1+9+25+49+81
$$

165

The practice of dhikr by using certain numbers as a standard is a common practice in the practice of Tariqa worship. This practice has become a culture for a group of Tariqa and their followers. Some people also say Tariqa as a part of the Sufi culture in Islam (Le Gall, 2005). This approach in mathematics education research is an area of ethnographic investigation, many people call it the ethnomathematics, a term pioneered by D'Ambrosio (1985).

The ethnomathematics content disclosed above is a phenomenon written etic by researchers based on observations in the field. It means that the followers of the TNQ are not concerned with the phenomenon put forward by the researchers, unless the researchers can show that these phenomena are indeed realized or even understood by the cultural-religious groups themselves. To be honest, this question or objection was accepted by the author during the dissemination and Focus Group Discussion (FGD) on ethnomathematics. In other words, this paper is also intended to answer this objection.

This paper is an attempt by both authors to focus on the same research as previous research, which is improved by bringing up mathematical concepts that respondents are aware of and understand as an important part of the dhikr process. It is not only that, authors try to contrast mathematical phenomena and mathematical concepts by separating them into different sections and providing several descriptions of the discussion. Mathematical 
phenomena are operationalized as things that can be witnessed with the senses and can be explained more logically through mathematical representations put forward etic by the researcher on the object under study. Meanwhile, the mathematical concept is operationalized as a mental entity to understand an object, idea, or event through logical representations and through a series of mathematical thinking processes. The mathematical concept is exposed by the researcher through two approaches, emic and etic.

Exposure of ethnomathematics phenomena in this paper was carried out through two perspectives, namely the intrinsic perspective according to the subject being studied itself on phenomena with emic techniques and extrinsic perspectives according to researchers and outside observer analysis including theoretical reviews with etic techniques. Therefore, the researcher maximally interacts deeply and continuously with the object of the research. This is consistent with Hoare's opinion that ethnography can increase theoretical sensitivity through continuous observation and participation in cultural groups (Hoare et al., 2013).

Emic and etic were originally conceived by linguistic figures (Pike, 1967) then used in examining the sounds used in a particular language (phonetics) and explaining universal properties that go beyond that language (phonemic) (Tripp-Reimer, 1984). In present-day linguistics, emic and etic are broadened to observe how 'language' is according to speakers and according to those who listen to speech (Hoare et al., 2013). Currently, many ethnographic researchers have adopted this idea to clarify their observations of how phenomena are perceived by people in their own cultural groups and how phenomena are perceived by outsiders (Godina \& Rachelle, 2000).

However, in this case, the authors prefer to use the etic and emic concepts used in ethnomathematics by Orey \& Rosa. Besides having a mathematical background, Orey \& Rosa explained about the emic approach which investigates mathematical phenomena and their relationships and structures through the perspective of people in certain cultural groups. They underlined that certain research techniques used in acquiring emic mathematical knowledge have nothing to do with the nature of knowledge. However, ethical techniques are believed to have little influence on the nature of knowledge (Orey \& Rosa, 2015). For this reason, observation and in-depth interview techniques (including asking several questions) to several research subjects and outside observers were selected by the researcher as a method of achieving more established analysis.

Some research results showed that implementing Tariqa has succeeded in giving a positive influence on social life in society which includes three aspects, namely in religious life, social life and economy (Alviani, 2017). Another report mentions a positive correlation between religious appreciation and thought, and economic behavior among the Ikhwan (Shulthoni, 2011). In the psychological aspect, the implementation of the dhikr method is identified as being able to increase self-esteem (self-esteem) (Nurhasanah, 2015). In addition, the influence of dhikr in Tariqa was also identified as having a positive impact on the change in the character of students, namely: religious, honest, disciplined, hard work, humble, respect for knowledge, and respect and courtesy (Linnaja, 2018). Even further, dhikr has been identified to play a role in educating a person spiritually and physically (Syed Abdurrahman, 1998). The energy of dhikr that results from remembering Allah SWT. including being able to strengthen faith, build self-potential, generate moral energy, increase patience, and build selfawareness (Amin \& Haryanto, 2008). Authors' analysis of these research reports leads to a conjecture that dhikr which has a positive influence on the practitioner, if it is conducted in 
the right manner, both in quality and quantity. Therefore, practically, a mathematical concept is needed in many dhikr practices.

\section{METHODS}

The author used a qualitative approach (Creswell, 2007) with ethnographic methods. Because what the author doing is a mathematical study of a group of people, the author refers to an ethnomathematics method proposed by D'Ambrosio (D'Ambrosio, 1990; D'Ambrosio, 1998; D'Ambrosio \& D'Ambrosio, 2013). There are two ethno-mathematical contents discussed in this paper, namely mathematical phenomena and mathematical concepts through etic and emic approaches. (Orey \& Rosa, 2015). The focus of the research was in Pondok Pesantren Suryalaya-Sirnarasa Panjalu, West Java, with 38 respondents. Convenience sampling and purposive sampling techniques were used to obtain representative respondents (Etikan et al., 2016). Meanwhile, the author's data analysis and observation techniques used a phenomenological study to obtain a subjective meaning of the phenomena experienced by the respondents (Azharini \& Nency, 2019; Hajaroh, 2010; Nindito, 2005; Sobur, 2014). The research flowchart was carried out in the following stages.

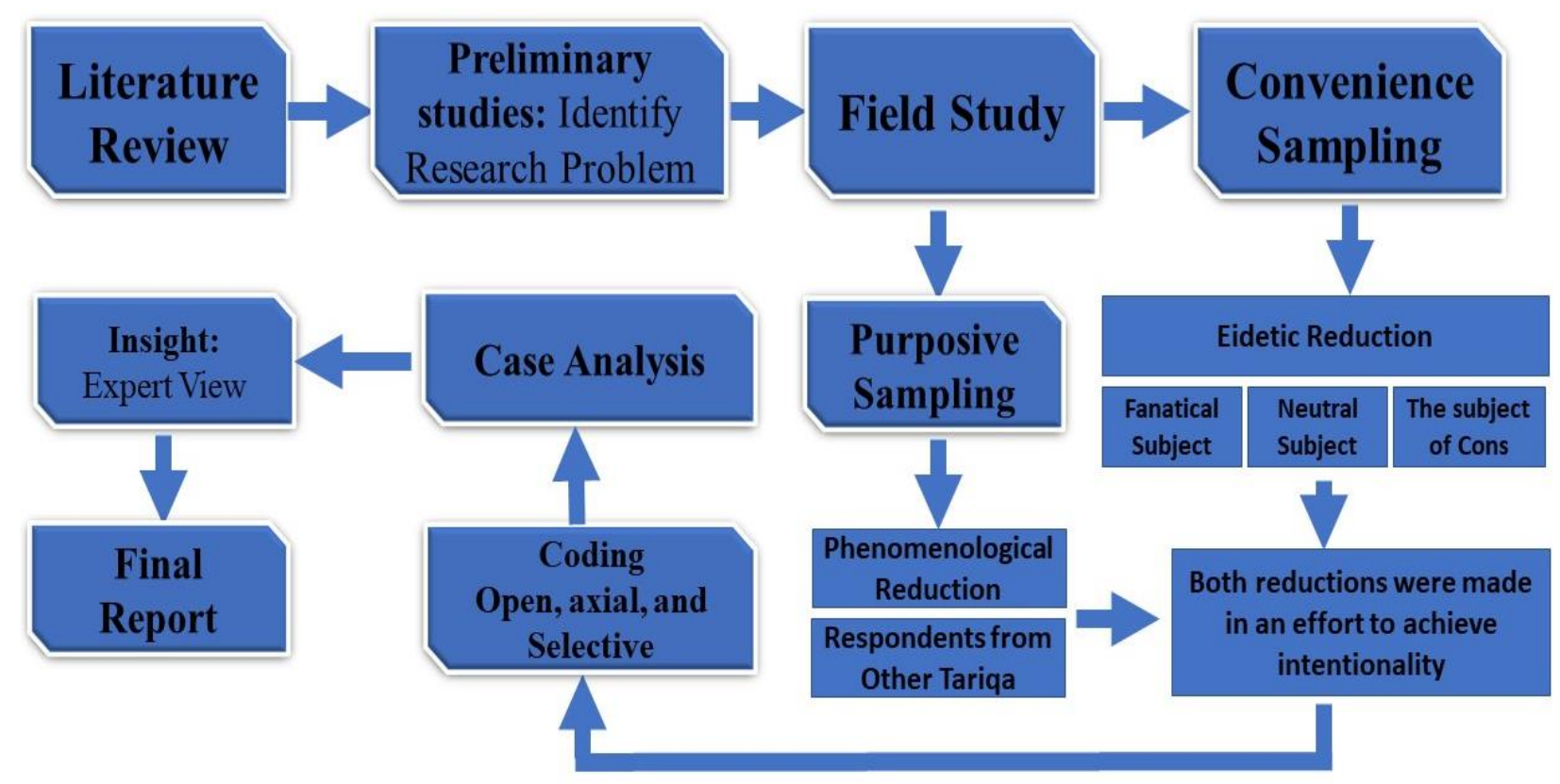

Figure 2. Research Flowchart

The literature review was carried out to strengthen the philosophical foundations of mathematics and its relationship to the belief, more specifically with the practice of dhikr. Authors conducted a preliminary study to identify research problems. To achieve intentionality, the authors carried out two types of reduction, namely eidetic reduction and phenomenological reduction which were carried out on fanatical subjects, contra subjects, and subjects from other similar groups (respondents who came from the other Tariqa). The analysis was carried out after the coding process is complete. Although the authors were careful and tried to be as neutral as possible, the results of the analysis were consulted with experts to discuss potential ethical issues. 


\section{RESULTS AND DISCUSSION}

\section{Mathematical Phenomena}

- Grid Square Phenomenon 5x5 Order of 5 First Odd Numbers

This phenomenon is a continuation of the previous phenomenon regarding the sum of the squares of the first five odd numbers to form 165 (Yulianto et al., 2020). If these five numbers are distributed into each row and column in a square grid with the order of $5 \times 5$ then the arrangement shown below will be obtained. Each row and column do not have the same repeated number, all are uniquely formed by numbers $1^{2}+3^{2}+5^{2}+7^{2}+9^{2}$.

\begin{tabular}{|c|c|c|c|c|c|c|}
\hline 165 & 165 & 165 & 165 & 165 & 165 & 165 \\
\hline 165 & $1^{2}$ & $5^{2}$ & $7^{2}$ & $9^{2}$ & $3^{2}$ & 165 \\
\hline 165 & $5^{2}$ & $9^{2}$ & $3^{2}$ & $7^{2}$ & $1^{2}$ & 165 \\
\hline 165 & $3^{2}$ & $7^{2}$ & $5^{2}$ & $1^{2}$ & $9^{2}$ & 165 \\
\hline 165 & $7^{2}$ & $1^{2}$ & $9^{2}$ & $3^{2}$ & $5^{2}$ & 165 \\
\hline 165 & $9^{2}$ & $3^{2}$ & $1^{2}$ & $5^{2}$ & $7^{2}$ & 165 \\
\hline 165 & 165 & 165 & 165 & 165 & 165 & 165 \\
\hline
\end{tabular}

Figure 3. Grid Square $5 \times 5$ of 5 First Odd Numbers

The order of 165 that can be formed from these five numbers is not unique, it means that we can still find other arrangements. This discovery is interesting not because of a mathematical game of numbers itself, but because it is supported by the fact that there is a Wifiq made by an Ikhwan TQN, KH. Irfan Zidni. The Wifiq is composed of nine numbers, they are $51,52,53,54,55,56,57,58$, and 59. Each number is uniquely arranged into nine boxes and the results for each column and row are the same, 165 .

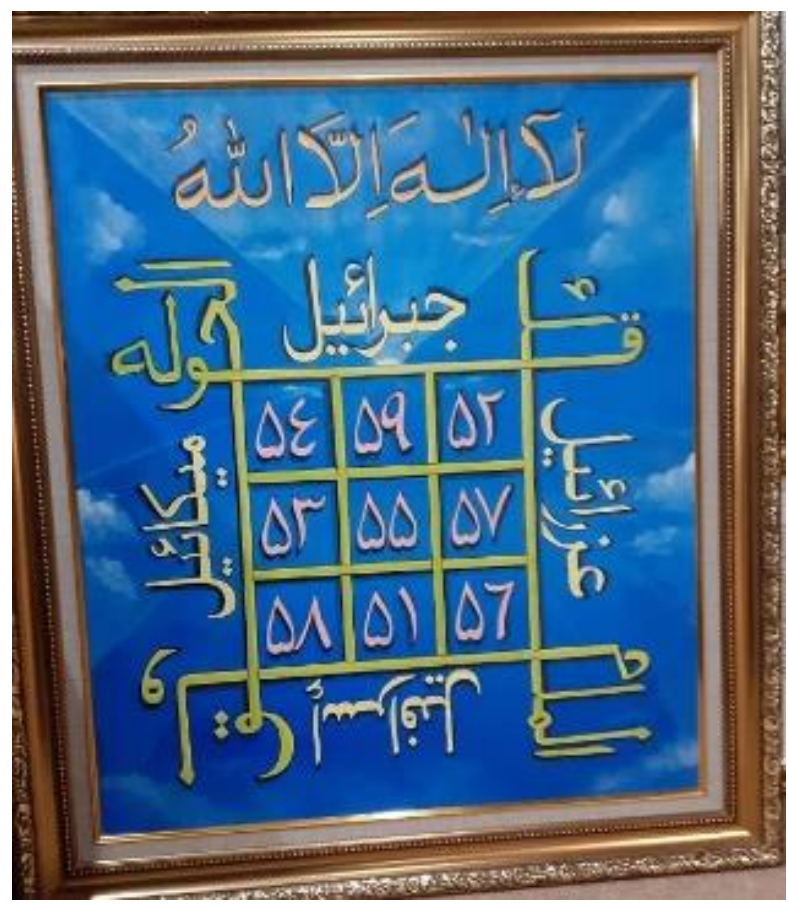

Figure 4. Wifiq of The Name of Syekh Muhammad Abdul Gaos

Source: The researchers' documentation was taken directly at the Sirnarasa 
Wifiq is a part of written language which is formed by letter elements, word elements, text elements, symbol elements, picture elements and number elements. But more than that, wifiq is related to the science of Asror (mystical power) which studies the secrets of a letter, such as shapes, characters, and images written and constructed that contain transactional relationships between humans and God, so some people call them 'amulets' (Qosim, 2016). Unfortunately, researchers have not succeeded in digging more about the meaning of wifiq in the image to the creator directly due to limitations during the Covid-19 Pandemic.

Nevertheless, the author managed to obtain facts in the form of recognition through interviews from one of the respondents, an Ikhwan TQN who was also an academic who was domiciled in Yogyakarta at that time. He said, in 2016 he was faced with the experience of dealing with a woman who was possessed. As a psychotherapist who was pursuing the science of dhikr, he tried to handle the case in a different way. He showed a photo of Syekh Muhammad Abdul Gaos on his cellphone to a woman who was possessed. In fact, the woman was experiencing pain and screaming 'ampuuun...ampuuuu...jauhkan...jauhkan' [give up...give up...give up]. Then he asked the genie who possessed the woman to come out and get away. This magical way of working is similar to how wifiq works.

- 5 Privileged Phenomenon Result of Number Operations from Numbers 1, 6, and 5

According to Pierce's semiotic theory, the sign is in its triadic relation to the object and the interpretant (Pierce, 1998).

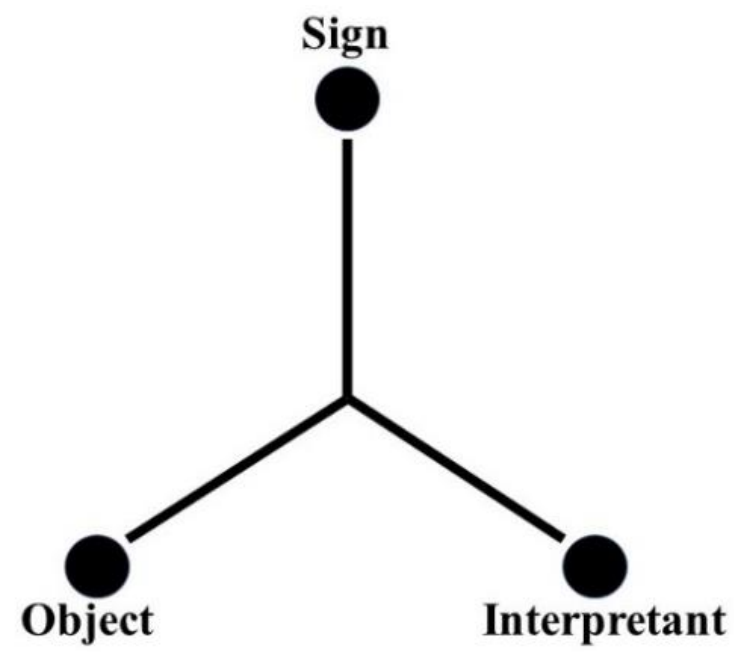

Figure 5. The sign in its triadic relation to the object and the interpretant (Semiotic Peirce) (Pierce, 1998).

According to the semiotic, numbers 1, 6, and 5 represent the concepts of Ihsan, Faith, and Islam (Yulianto et al., 2020). By paying attention to the sequence of numbers 1, 6, and 5, multiplying these numbers will produce number $1 \times 6 \times 5=30$. If added together will be $1+$ $6+5=12$. If deducted will become $1-6-5=-10$. If it is divided it will be 1:6:5= $1 / 3$. 
Table 2. Features of Sum and Product of 1,6 , and 5

\begin{tabular}{|c|c|c|c|c|c|c|}
\hline $\begin{array}{c}\text { Ihsan } \\
1 \\
\end{array}$ & $\mathrm{X}$ & $\begin{array}{l}\text { Faith (Iman) } \\
\quad 6 \\
\end{array}$ & $\mathrm{x}$ & $\begin{array}{l}\text { Islam } \\
5 \\
\end{array}$ & $=$ & $\begin{array}{l}\text { The number of Juz Al-Quran } \\
30\end{array}$ \\
\hline $\begin{array}{c}\text { Ihsan } \\
1 \\
\end{array}$ & + & $\begin{array}{l}\text { Faith (Iman) } \\
\quad 6 \\
\end{array}$ & + & $\begin{array}{c}\text { Islam } \\
5 \\
\end{array}$ & $=$ & 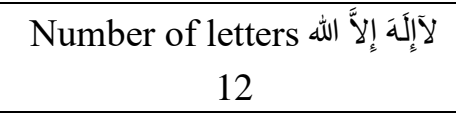 \\
\hline $\begin{array}{c}\text { Ihsan } \\
1\end{array}$ & - & $\begin{array}{l}\text { Faith (Iman) } \\
\quad 6\end{array}$ & - & $\begin{array}{l}\text { Islam } \\
5\end{array}$ & $=$ & $\begin{array}{l}\text { An Angel You Must Know } \\
\quad-10 \rightarrow|-10|=10\end{array}$ \\
\hline $\begin{array}{c}\text { Ihsan } \\
1\end{array}$ & $:$ & $\begin{array}{l}\text { Faith (Iman) } \\
\quad 6\end{array}$ & $:$ & $\begin{array}{c}\text { Islam } \\
5\end{array}$ & 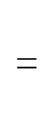 & $\begin{array}{l}\text { Concept of Qiyamullail } \\
\qquad 1 / 3\end{array}$ \\
\hline
\end{tabular}

The number 30 in Islam shows the number of Juz in the Quran. According to Figure 1,

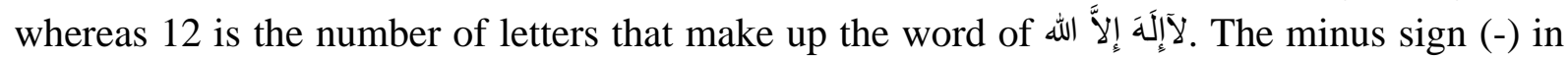
the third row of the table above can be removed by looking at the absolute value to $|-10|$ or equal to 10. The number 10 represents an angel that every Muslim must know. In Tariqa, recognizing angels is a step that needs to be taken in increasing spiritual understanding. These ten angels can be identified in each human being. Further discussion of this chapter will be described in the discussion section. Whereas 1/3 represents Qiyamullail as the information from the hadith from Abu Hurairah ra., that Rasulullah SAW. said

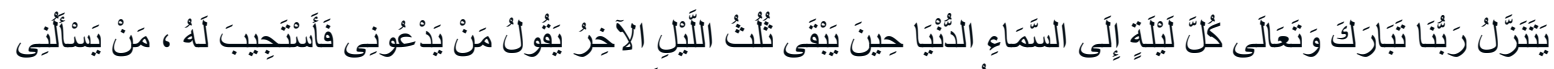

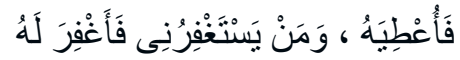

"God tabaroka wa ta'ala descends every night into the heavens of the world until the last third of the night remains, then He said: 'Whoever prays to Me, I will allow his prayer. Whoever asks of Me, I will definitely give it. And whoever asks forgiveness of Me, I will surely forgive '." (HR. Bukhari no. 6321 dan Muslim no. 758) (Muslim, 1992).

Muhammad bin Isma'il Al Bukhari delivered this Hadith in the chapter 'prayer at half the night' while Imam Nawawi mentioned the title in Sahih Muslim chapter 'the urge to pray and recite at the end of the night and the prayer is granted at that time' (Tuasikal, 2020). This is in line with the explanation of the Quran, Surah Al-Muzzammil verses 2-3.

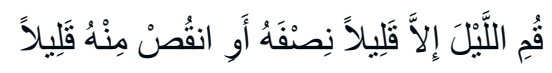

"Get up (for prayer) in the evening, except a little (of it), half or subtract a little from that half" [QS. Al-Muzzammil: 2-3].

TQN teaches night prayers along with dhikr since midnight which starts at $00.00 \mathrm{WIB}$ by starting a bath of repentance first.

- The phenomenon of the grammatical value of the sentences "IMAN", "ISLAM", and "IHSAN" form the number 651

Islam (science: figh), Iman (science: tauhid), dan Ihsan (science: Sufism) often called the Islamic Trilogy (religion) (Bahri, 2019; El-Bantani, 2010; Kafie, 1981; Majid, 1995; Murota \& Chittick, 1997; Noegroho, 2019; Quddus, 2007). Fiqh teaches knowledge about all the rules for implementing worship and Islamic law. Tauhid teaches about the oneness of Allah SWT. Along with dzat, asthma, nature, and af'al (deeds) Allah SWT. Meanwhile, Sufism teaches how to present Allah SWT. into oneself so that human behavior reflects praiseworthy morals. The three of them cannot be separated from each other. Some scholars even call it the Triumvirate of Religion (Rathony, 1972). 
Table 3. Pillars of Faith, Pillars of Islam, and Pillars of Ihsan

\begin{tabular}{ccc}
\hline Pillars of Faith & Pillars of Islam & Pillars of Ihsan \\
\hline 6 & 5 & 1 \\
\hline
\end{tabular}

In addition to the five pillars of Islam that must be fulfilled by Muslims (Syahada, prayer, zakat, fasting, hajj) and the six pillars of faith that believers must believe (Faith in Allah SWT., Faith in the angels of Allah SWT., Faith in the Scripture of God., Faith in Allah's Apostles, Faith in the Last Day, and Faith in Allah SWT). There is one pillar of Ihsan that cannot be separated in order to achieve religious perfection, namely "worshiping Allah SWT., as if seeing Him, and if you are unable to see Him, then Allah is all-seeing" (Anugrah et al., 2019) . This is based on the Hadith Jibril narrated by Muslim RA. At that time the angel Jibril 'alaihis sallam came to the assembly of the Prophet Muhammad SAW. and his companions in human form, then asked the Prophet Muhammad SAW. some questions.

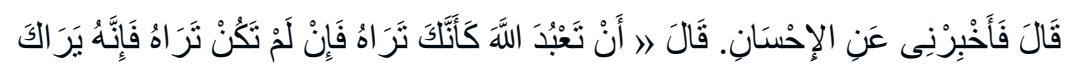

"'O Messenger of Allah, what is ihsan?' He replied, 'you worship Allah as if you saw Him, so if you do not see Him then indeed He will see you" (H.R. Muslim No. 102) (Muslim, 1992)

One of the researchers' notes regarding the order to enter Islam is the statement of Syekh Muhammad Abdul Gaos qs., "Abah mah can manggih parentah asup Islam kanu teu Iman, aya oge 'lakum dīnukum wa liya dīn [QS. 109: 6]' [Abah did not find an order to enter Islam for people who do not believe in Allah, there is also 'lakum dīnukum wa liya dīn (for you your religion, for me my religion)]. Parentah asup Islam kanu Iman mah 'udkhulụ fis-silmi kāffah' [The order to enter Islam to those who believe is 'udkhulụ fis-silmi kāffah' (Enter into Islam perfectly)]. This means that Abah (Abah: nick name of Syekh Muhammad Abdul Gaos qs) has not found an order to enter Islam for those who do not believe, there is one 'lakum dīnukum wa liya dīn [QS. 109: 6]' which means for you your religion, for me my religion. The order to enter Islam to those who believe 'udkhulụ fis-silmi kāffah' (enter into Islam as a whole / perfectly).

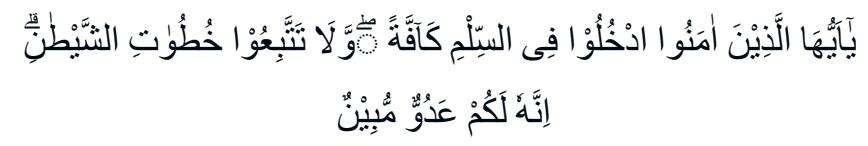

O you who believe in God! Enter into Islam as a whole, and don't follow Satan's steps. Really, he's a real enemy to you [QS. Al-Baqoroh: 208].

According to Table 3 about the pillars of faith, the pillars of Islam, and the pillars of Ihsan, the three form the number 651 , where the number 651 is the largest number composed of numbers 1,6 , and 5 . 
Table 4. 3 Digits Arrangement of Numbers 1, 6, 5

\begin{tabular}{cccc}
\hline & Arrangement of Numbers & & Explanation \\
\hline 1 & 6 & 5 & The Number of Dhikr \\
\hline 1 & 5 & 6 & Smallest Number Combination \\
\hline 6 & 1 & 5 & - \\
\hline 6 & 5 & 1 & Largest Number Combination \\
\hline 5 & 1 & 6 & (According to Table 3) \\
\hline 5 & 6 & 1 & Reversed Number of Dhikr \\
\hline
\end{tabular}

First, the grammatical value of the sentence Iman (الإيمان) which is composed of 5 letters is as follows:

Table 5. Grammatical Value of Term of Faith (الإيمان)

\begin{tabular}{|c|c|c|c|c|c|}
\hline ن & 1 & ק & ي & 1 & \\
\hline 50 & 1 & 40 & 10 & 1 & \\
\hline
\end{tabular}

Second, the grammatical value of Islamic sentence (ألإنْنَام) which is composed of 5 letters is as follows:

\begin{tabular}{|c|c|c|c|c|c|}
\hline م & 1 & J & س & 1 & \\
\hline 40 & 1 & 30 & 60 & 1 & \\
\hline
\end{tabular}

Third, the grammatical value of the sentence Ihsan (احسان) which is composed of 5 letters is as follows:

Table 7. Grammatical Value of Term of Ihsan (احسان)

\begin{tabular}{llllll}
\hline$\dot{0}$ & 1 & $\omega$ & $\tau$ & 1 & \multirow{2}{*}{120} \\
\cline { 1 - 4 } & 1 & 60 & 8 & 1 & \\
\hline
\end{tabular}

There are two sentences of dhikr that are recited in the TQN, namely Dhikr Jahar with the sentence لَآلَّة إِلاً الله and Dhikr Khofi which cannot be spoken verbally but only read silently with the sentence (الله الله (الله Talqin deputy of Abah Aos, KH. Epi Ruhiat Ganefi explained that the two sentences were implanted in Latifatul Qolbi and bound by two lights that will never be separated, namely 'Nurulloh' and 'Nur Muhammad'.

Fourth, the grammatical value of the sentence Dhikr Jahar (لآلَإلَهَ إِلاًَ الله) which is composed of 12 letters as in Figure 1 is 165.

Fifth, the grammatical value of the sentence Dhikr Khofi (الله الله) which is composed of 12 letters is as follows:

Table 8. Grammatical Value of Term Dhikr Khofi (الله الله)

\begin{tabular}{|c|c|c|c|c|c|c|c|c|}
\hline هـ & J & $J$ & 1 & هـ & J & $J$ & 1 & \\
\hline 5 & 30 & 30 & 1 & 5 & 30 & 30 & 1 & \\
\hline
\end{tabular}

If all the grammatical values of the sentence Iman, Islam, Ihsan, Dhikr Jahar and Dhikr Khofi TQN are combined, the value is 651 . 
Table 9. Combined of The Term of Iman, Islam, Ihsan, Dhikr Jahar, and Dhikr Khofi formed 651

\begin{tabular}{|c|c|c|c|c|}
\hline Pillars & Term (Latin) & Term (Arabic) & Letters & Grammatical Values \\
\hline 6 & Iman & (الإيمان) & 5 & 102 \\
\hline 5 & Islam & (ألإنسنالَم) & 5 & 132 \\
\hline 1 & Ihsan & (احسان) & 5 & 120 \\
\hline$\geq 165$ & Dhikr Jahar & 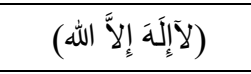 & 12 & 165 \\
\hline & Dhikr Khofi & (الله الله) & 8 & 132 \\
\hline \multicolumn{4}{|c|}{ JUMLAH } & 651 \\
\hline
\end{tabular}

This grammatical value of 651 matches the number of pillars of Iman (6), Islam (5), and Ihsan (1). These three Islamic trilogies, if illustrated as a building / house, have mutually reinforcing roles where the pillars of faith are the foundation, the pillars of Islam as the pillars, and the pillars of Ihsan as the roof (Wahyudi, 2014). In addition, this grammatical value also matches the 3-digit largest number arrangement formed from numbers 1, 6, and 5, namely the number 651 as explained in table 4 .

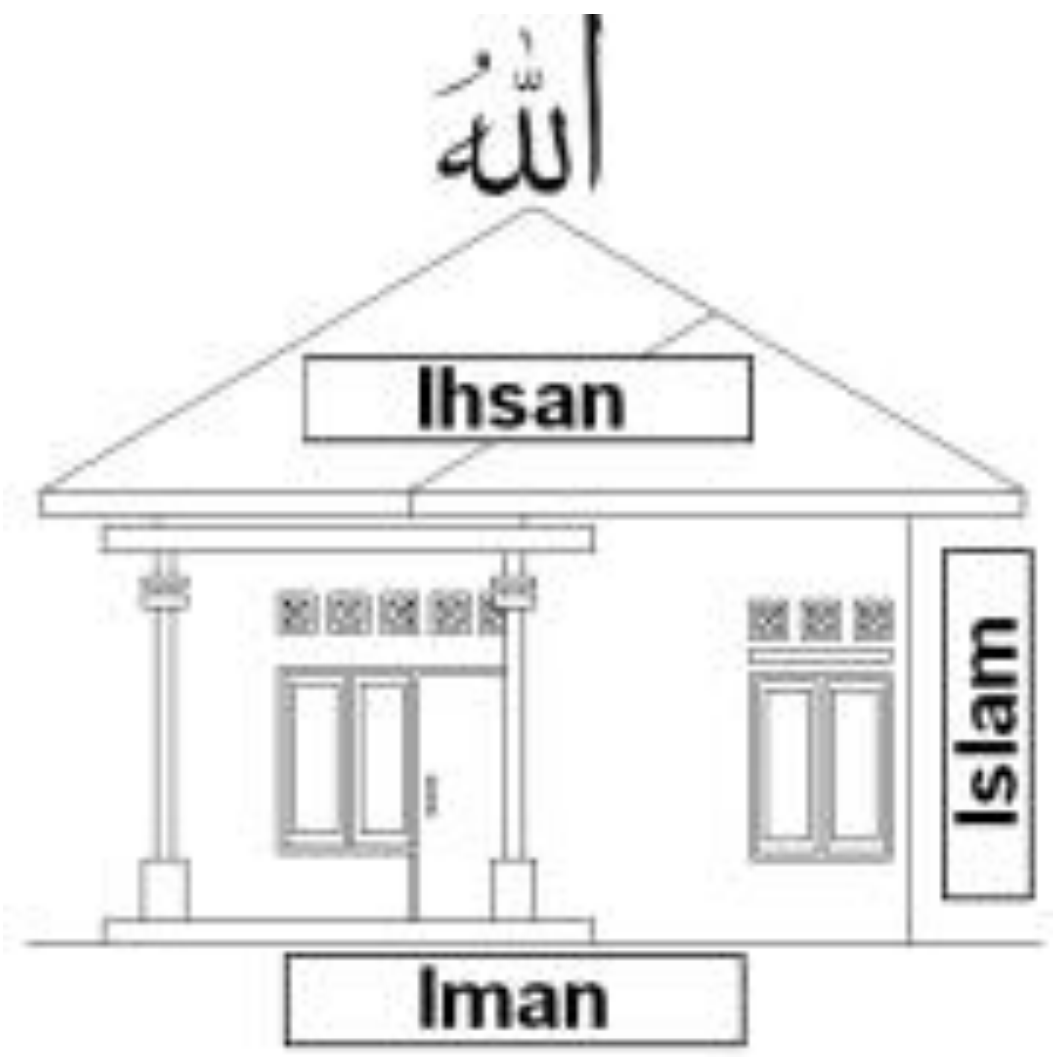

Figure 6. Illustration (picture) of Faith, Islam and Ihsan (Wahyudi, 2014)

- The Phenomenon of Dhikr Khofi Answering Science of 4000 Names of Allah SWT. According to the Tafsir Yaasiin Hamami

The majority of Muslims understand that the number of Asmaul Husna is 99 names. Meanwhile, according to Thabathaba'i in the interpretation of Al-Mizan, it says more than that, to be precise there are 127 names (Mahmudi, 2018). In the TQN teachings, it is 
explained that Allah SWT. has 4,000 names. This information is also contained in several references such as the Yasin Hamami interpretation, the Istira Badzi interpretation, and from several Hadiths that are stated that Allah SWT. has 4,000 Asma of which 1,000 is only Allah SWT. who knows, 1,000 is stored in Lauhil Mahfudz, 1,000 is only known to the angels, 300 in the Torah, 300 in the Zabur, 300 in the Bible, and 99 in the Alquran (Adawiyah, 2015; Mahmudi, 2018). From this information, of course where is one more asthma Allah SWT. to be the big question.

Table 10. The Number of Names of God According to Tafsir Hamami

\begin{tabular}{lrl}
\hline \multicolumn{1}{c}{ Place of Asma Allah } & Numbers & Number categories \\
\hline Keep it secret by Allah SWT. & 1.000 & Even \\
\hline In the Angels & 1.000 & Even \\
\hline In the Lauhul Mahfudz & 1.000 & Even \\
\hline In the Torah & 300 & Even \\
\hline In the Zabur & 300 & Even \\
\hline In the Bible & 300 & Even \\
\hline In the Al-Quran & 99 & Even \\
\hline
\end{tabular}

Asmaul Husna in the Al-Quran is 99 names (odd), while the number of names of Allah SWT. in other books is even. Tariqa Qodiriyyah Naqsyabandiyyah explains that the name of Allah SWT. what is meant is stored in the Dhikr Khofi. This is based on the information from Syekh Muhammad Abdul Gaos himself and also Talqin Representatives who said that one Asma is stored in Dhikr Khofi is an Asma bag that accommodates 3,999 other Asma.

- The Phenomenon 12 in Dhikr Laa Ilaaha Ilallah

The specialty of number 12 in the Dhikr Laa Ilaaha Ilallah has been previously discussed in the 2nd phenomenon that the sentence (لآَإلَََ إلإَّا الله) consists of 12 letters. The bearer of the teachings of Laa Ilaaha Ilallah was called the messenger of Allah SWT., Namely Muhammad SAW. or who is called Muhammaddurrasulullah. In Arabic script it is written as محمّدً رسولُ الله محمّدً رسولُ الله The sentence also composed of 12 letters.

Table 11. Letter Arrangement محمّد رسولُ الله

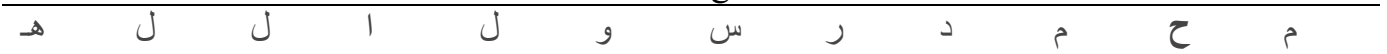

It is more interesting that these 12 not only label the sentence of Dhikr Jahar in the TQN teachings, but also show the number of names of the sentence (لآلآلَإلَََ إِلَّ الله) itself. Researcher's notes delivered by Syekh Muhammad Abdul Gaos mentioned that (لآلَإلََ إلإِا اللها read as Laa Ilaaha Ilalloh has 12 names. Further search results were found by researchers in Syarrah Kitab Uquudul Jumaan p. 52 (Zidni, 2015), Syekh Muhammad Abdul Gaos explained that Laa ilaaha ilallah has many names, nine of which are mentioned Kalimatus Samawati wal Ardh; Kalimatul Ulya; Kalimatut Tauhid; Kalimatul Ikhlas; Kalimatut Taqwa; Kalimatut Toyibah; Kalimati Da'watul Haqq; Kalimatul Wusqo; and Kalimat Tsamanal Jannah (Harga Surga). While the next three names were obtained by researchers through in-depth interviews from an Ajengan who is also a TQN Brotherhood. He said another name from Laa Ilaaha Ilalloh are Kalimatun Najat; Kalimatul Dzikr; and Kalimatul Adhim. 


\section{Mathematical Concept}

One of the strict mathematical concepts used by the TQN brothers in practicing Dhikr Jahar is the concept of counting. This is based on the provisions of the TQN dhikr teaching itself where the number of Dhikr Jahar is at least 165 times per prayer. Because Dhikr Jahar that is read every after prayer is not small number, almost every Ikhwan TQN has its own concept of dhikr either by using a counting aid for dhikr, namely tasbih or using fingers.

There are many kinds of dhikr number that are the mainstay of each Ikhwan TQN, including 165, 201, 241, 561, and 2500. Each brother has its own arguments in choosing the number of Dhikr that he carries out. Here are some concepts for calculating the number of Dhikr that the Ikhwan TQN use:

- $\quad$ The concept of calculating the number 165 Dhikr

The Brotherhood who relied on 165 as the number of Dhikr based on the teachings when Talqin dhikr TQN had to be at least 165 times. There are 3 ways for the Ikhwan to calculate the number 165 during dhikr, namely by using his fingers, prayer beads with 99 seeds and prayer beads with 165 seeds.

The TQN brothers who do dhikr using their fingers are classified as rare or difficult to find. Almost every Ikhwan that the researchers met all had prayer beads. However, in several cases the researchers also found that the brother who made dhikr with his fingers was in two ways, either the tasbih was left behind or he was a new brother. They use the concept of multiplication where each finger consists of three segments (usually they use the right finger as the unit and the left finger as a sign).
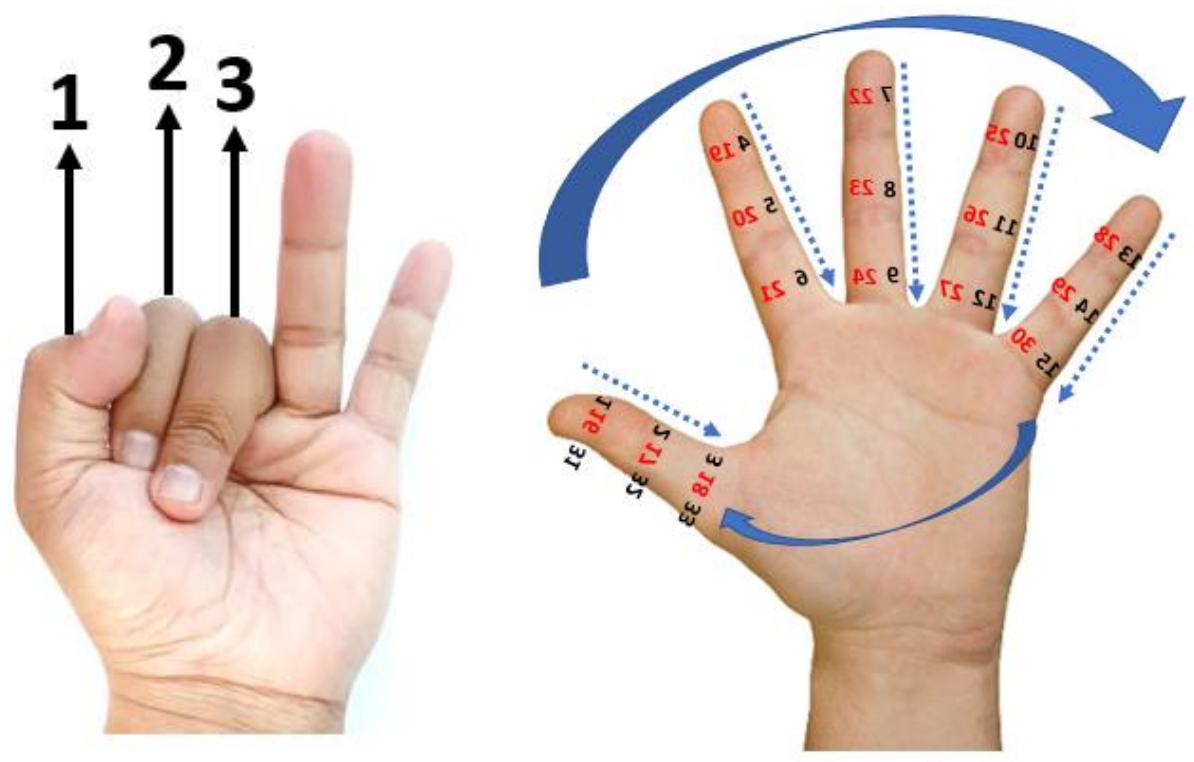

Figure 7. Methods of Recitation with Fingers Model A

Look at the picture of the right hand in Figure 7 which illustrates the concept of counting 165 by means that each finger has three segments in the order from the thumb to the little finger in the following cycle:

- Thumb : 3 knuckles $(1,2,3)$

- Index Finger $\quad: 3$ knuckles $(4,5,6)$

- Middle Finger $: 3$ knuckles $(7,8,9)$

- Ring Finger : 3 knuckles $(10,11,12)$

$$
\begin{array}{ll}
x 3 \text { cycles }=9 & \text { knuckles } \\
x 2 \text { cycles }=6 & \text { knuckles } \\
x 2 \text { cycles }=6 & \text { knuckles } \\
x 2 \text { cycles }=6 & \text { knuckles }
\end{array}
$$


- Pinky : 3 knuckles $(13,14,15)$

$$
\begin{array}{ll}
x 2 \text { cycles } & =6 \text { knuckles } \\
\text { Total } & =33 \text { knuckles }
\end{array}
$$

Every two cycles count the right radius of 33 segments indicating the number of Dhikr is $33 \mathrm{x}$, so one finger (starting from the thumb) of the left hand is folded as a sign of the number of Dhikr is $1 \times 33$. So, in picture 2 above which shows 3 fingers (thumb number 1 , index finger number 2 and middle finger number 3 and so on in the picture) the left finger is folded showing the number $3 \times 33=99$. So, to reach the number 165 the Ikhwan used the same method until all the left fingers were folded so that the number $5 \times 33=165$ was obtained.

There is a concept of counting 165 using the other fingers which are slightly different. Compared to the previous concept, this second concept is different in how to travel the number 33 on the right finger which is only taken in one cycle.
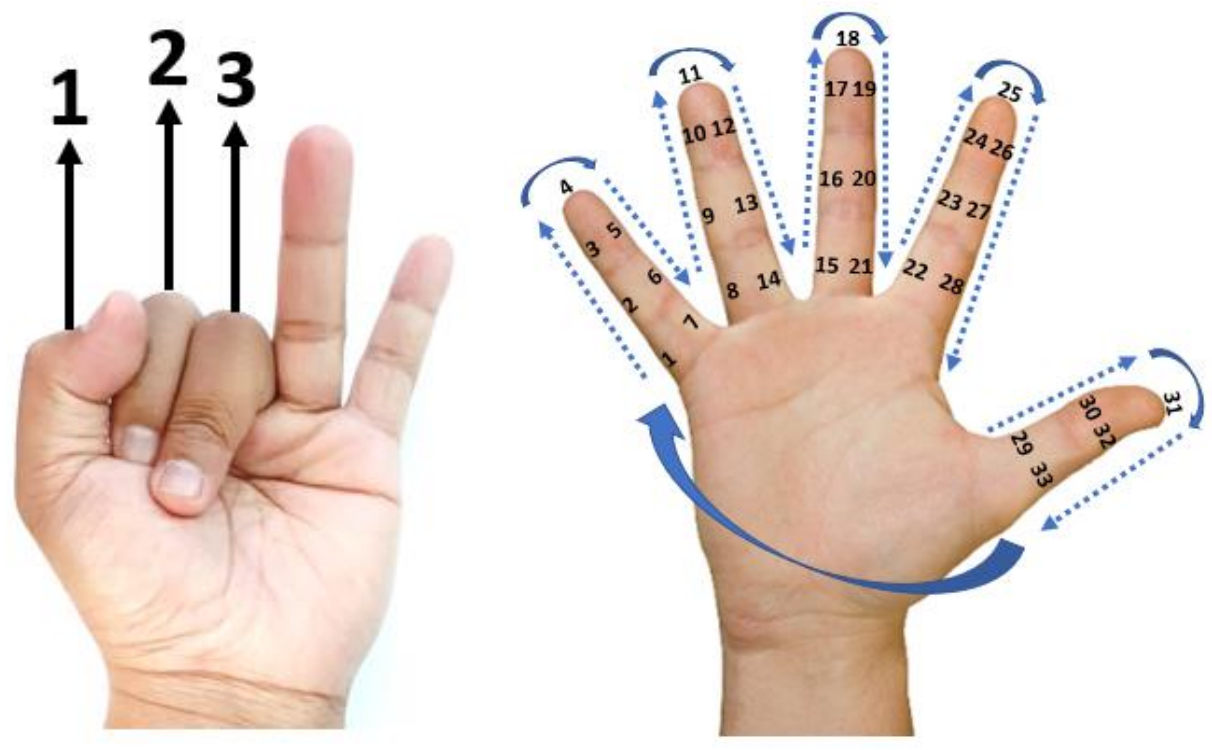

Figure 8. Methods of Recitation with Fingers Model B

The number 33 is taken in 1 cycle through 5 right fingers in the following order:

- Pinky

- Ring Finger

- Middle Finger

- Index Finger

- Thumb Total
: 3 knuckles $x 2+1=7$

: 3 knuckles $x 2+1=7$

: 3 knuckles $x 2+1=7$

: 3 knuckles $x 2+1=7$

$: 2$ knuckles $x 2+1=5$

: 33 numbers
(Look at No. 1-7 on the figures 8)

(Look at No. 8-14 on the figures 8)

(Look at No. 15-21 on the figures 8)

(Look at No. 22-28 on the figures 8)

(Look at No. 29-33 on the figures 8)

Thus, the image of the left hand in Figure 2 (folded thumb, forefinger and middle finger) shows the number of Dhikr $3 \times 33=99$. So, to get 165 it takes the five left fingers folded (5x33).

Most of Ikhwan TQN who made 165 Dhikr used 99 seed beads for their calculation aids. Some of them also use special prayer beads with 165 seeds. The phenomenon of these 165 beads is relatively rare and is only found in TQN brothers. 


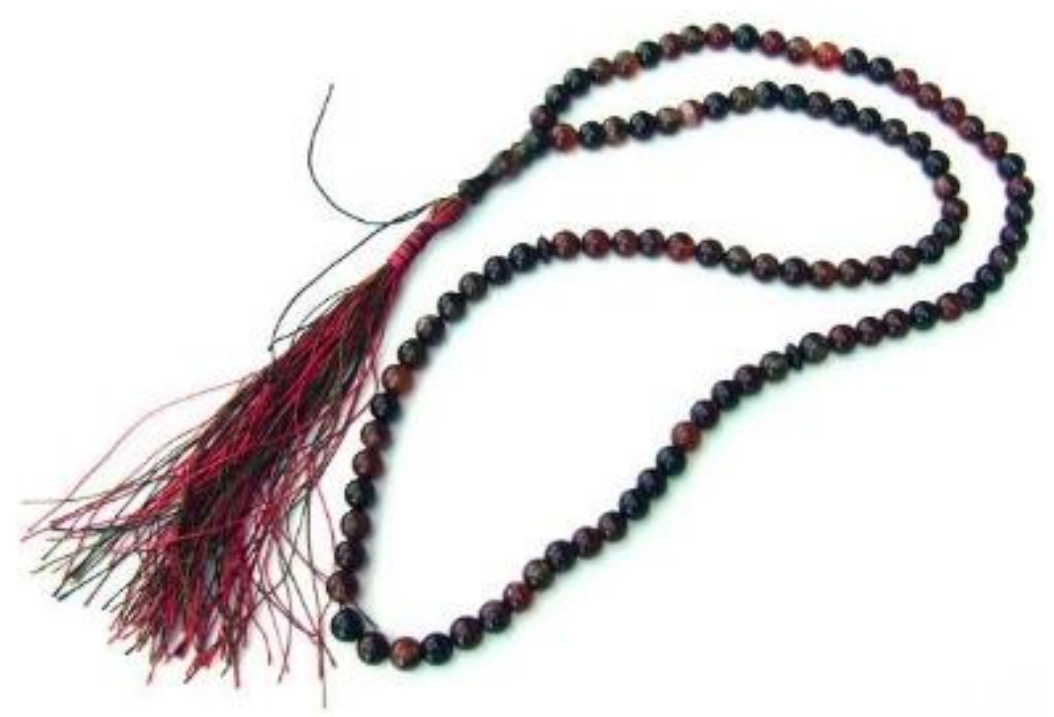

Figure 9. Tasbih 99

The Ikhwan who performed 165 Dhikr with the tool of 99 seeds of prayer beads used the concept of simple counting. In the 99 seed beads there is a mark / partition for every 33 seeds.

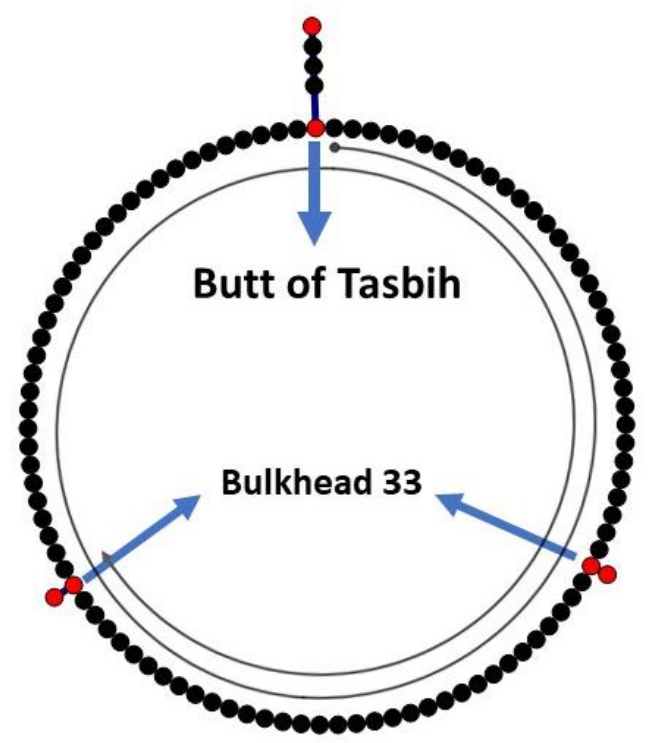

Figure 10. Mathematical Model of Tasbih 99

Figure 10 shows a model of 99 seed beads consisting of 2 bulkheads and 1 base of prayer beads $(33+33+33)$. To reach the number 165 the Ikhwan started counting from the base of the prayer beads.

$$
\begin{array}{ll}
1 \text { base (round) } & : 1 \times 99 \\
2 \text { dividers } & : 2 \times 33 \\
\text { Total } & : 165
\end{array}
$$

Another tool for counting is 165 seed beads. Usually, these beads are sold in the Manaqib event of Syekh Abdul Qodir Jaelani qs. once a month at Pondok Pesantren Suryalaya and Pondok Pesantren Sirnarasa. 


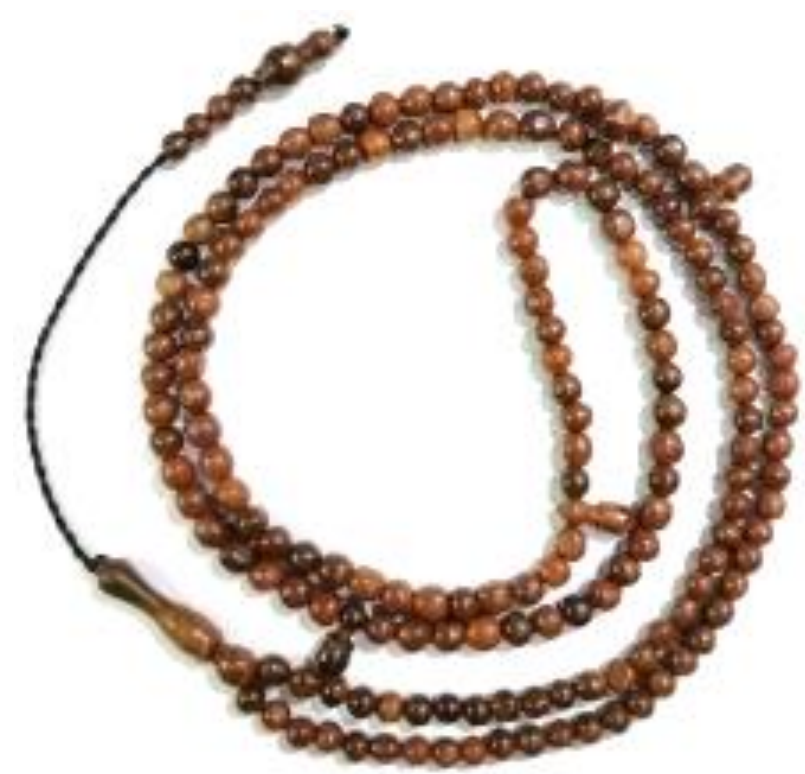

Figure 11. Model of Tasbih 165

The tasbih 165 items has two bulkheads which limit the tasbih to 33 items, 99 items, and 33 items. In other words, Ikhwan who recite 165 Dhikr with this type of prayer beads only need to do it with 1 round of prayer beads.

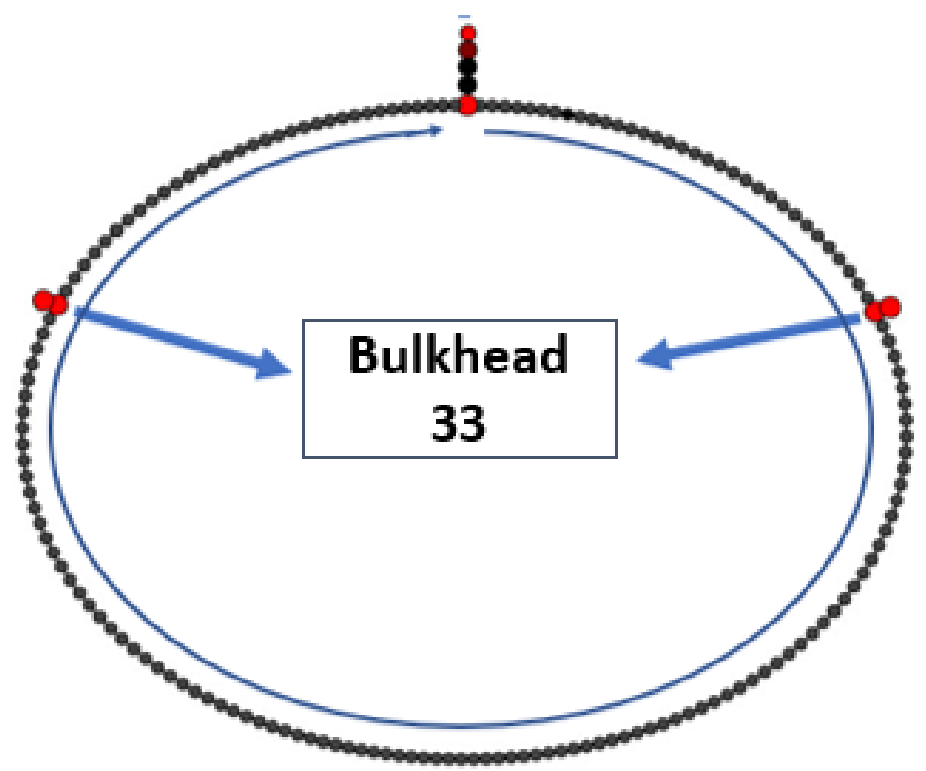

Figure 12. Mathematical Model of Tasbih 165

- The Concept of Counting 201 Dhikr

Some Ikhwan there are those who practice 201 Dhikr Jahar in every time they pray. This is based on the consideration of the Dhikr Jahar recommendation of at least 165, but more is better. Some respondents who practice the 201 Dhikr have two strong arguments, namely applying the concept of not being stingy with themselves and chasing the number 1000 in one day (through 5 prayer times). Many of the Ikhwan who practice the number 201 believe that there is a spiritual secret by fulfilling 1000 Dhikr a day.

To reach the number 201, there are several mathematical concepts used by the brothers, namely by using fingers or prayer beads. Practitioners of dhikr with the number 201 using their fingers are almost difficult to find because they always carry prayer beads at all times. 
However, some respondents who practice 201 Dhikr with their fingers are more likely to use their fingers with Model B (Figure 7). To reach 201 the Ikhwan use Model B (Figure 7) with a process of 6 cycles of the right hand plus 3 meaningful Dhikr $=6 \times 33+3$

$$
\begin{aligned}
& =198+3 \\
& =201
\end{aligned}
$$

Most of the Ikhwan who practice 201 Dhikr use the tool to count 99 beads.

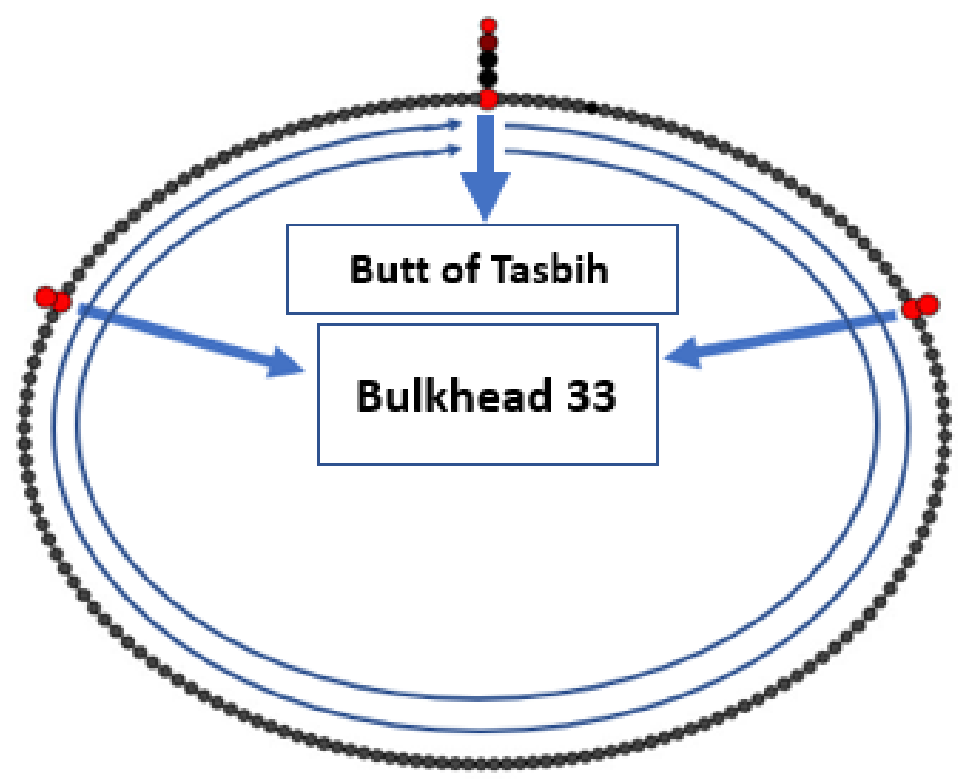

Figure 13. Mathematical Model of Dhikr 201 by Using Tasbih 99

To reach the number 201 with 99 beads is very simple, with only 2 tasbih cycles $(99+1$ base of tasbih $=100)$ plus 1 or the value of $2 \times(99$ beads +1 base seed $)+1$ or $2 \times 100+1$ or equal to 201 .

- The Concept of Counting 241 Dhikr

The Ikhwan who practice 241 Dhikr every time they pray rely on the same arguments as 201 Dhikr but the limit that they pursue is 1200 in 1 day. In other words, in one day at least 5 prayers will be filled with Dhikr x 241 or the same as 1205 .

The researcher identified two concepts of counting the number 241 using the prayer beads tool with 99 beads. The researcher did not find Ikhwan who routinely practiced 241 Dhikr using the finger method, all of them used the 99 prayer beads tools. The first concept started with the technique of taking the number 41 first and then heading for 200. 


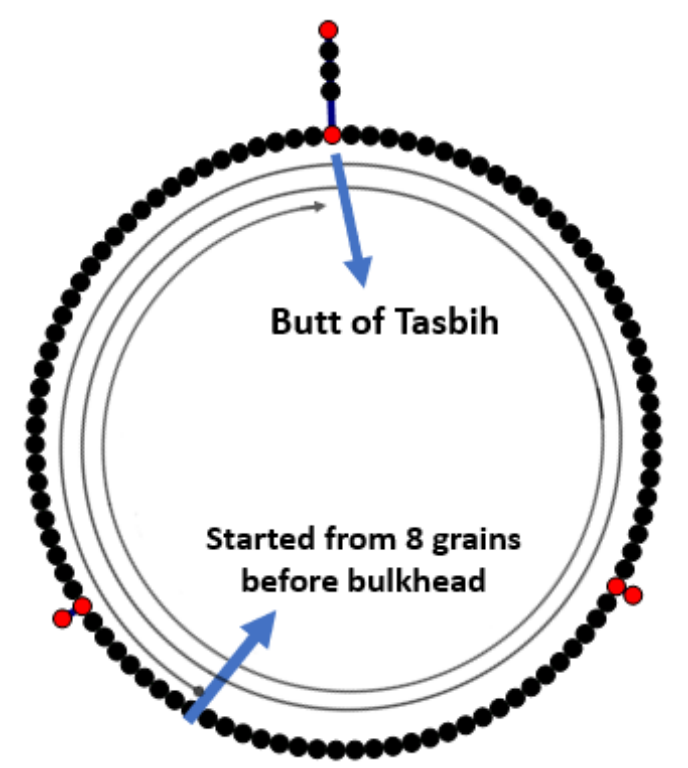

Figure 14. Mathematical Model of 241 Dhikr Type A

The process of counting dhikr starts from 8 seeds before the bulkhead begins in a clockwise direction and stops at the base of the prayer beads after going through more than 2 rounds (the base of the tasbih is also counted) in order to obtain 241

$$
\begin{gathered}
8+33+2 \times 100 \\
=41+200 \\
=241
\end{gathered}
$$

The second concept is to use the tasbih (which is always) starting from the base. This concept is not much different from the first concept. Ikhwan started from the first beads from the base as many as 2 rounds of prayer beads then added 1 bulkhead then added 8 seeds.

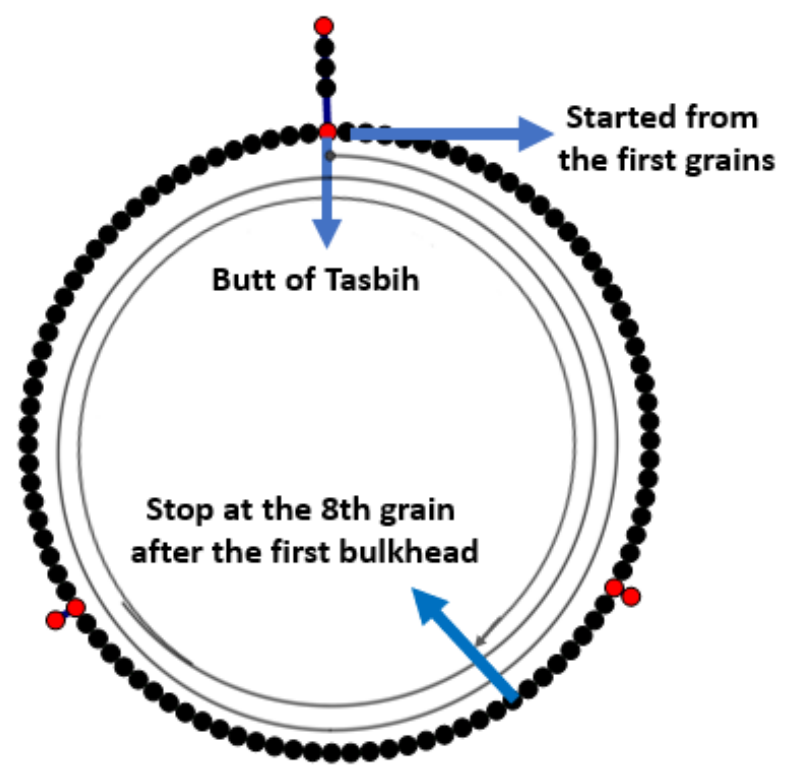

Figure 15. Mathematical Model of 241 Dhikr Type B

The number 241 is obtained through a process

$$
\begin{gathered}
2 \times 100+33+8 \\
=200+41
\end{gathered}
$$




$$
=241
$$

If we compare the mathematical model of number 241 type $\mathrm{A}$ and type $\mathrm{B}$, the same result is obtained or both fulfil the 'equal postulate'.

$$
\begin{aligned}
8+33+2 \times 100 & =2 \times 100+33+8 \\
41+200 & =200+41 \\
241 & =241
\end{aligned}
$$

- The Concept of Counting 561 Dhikr

The practice of Dhikr Jahar using the number 561 comes from the concept of more dhikr. This was reinforced by the words of Syekh Muhammad Abdul Gaos on many occasions, both in the management and 'shuhbah' (meeting or direct communication) of the Ikhwan TQN and Syekh, "loba keneh kabutuh mah zikirna sing loba, ulah cukup 165, balikeun 561" which means that if there are still many necessities of life, the amount of dhikr that is many, it is not enough, only 165 will be reversed to become 561 .

Through dhikr 561 for each after prayer, in one day there will be at least 5 Dhikr of prayers x 561 or equal to 2805 or more than 2500 . One of the respondents in this research also explained that there is a spiritual secret if in one day an Ikhwan able to perform Dhikr Jahar above 2500. This information is indirectly in line with Syekh Muhammad Abdul Gaos's explanation that a lot of dhikr is able to solve problems faster.

The researcher identified two concepts of counting the number 561 using the prayer beads tool with 99 beads. The researcher did not find Ikhwan who routinely practiced 561 Dhikr using the finger method, all of them used the 99 prayer beads. prayer beads $(99+1=$ $500)$.

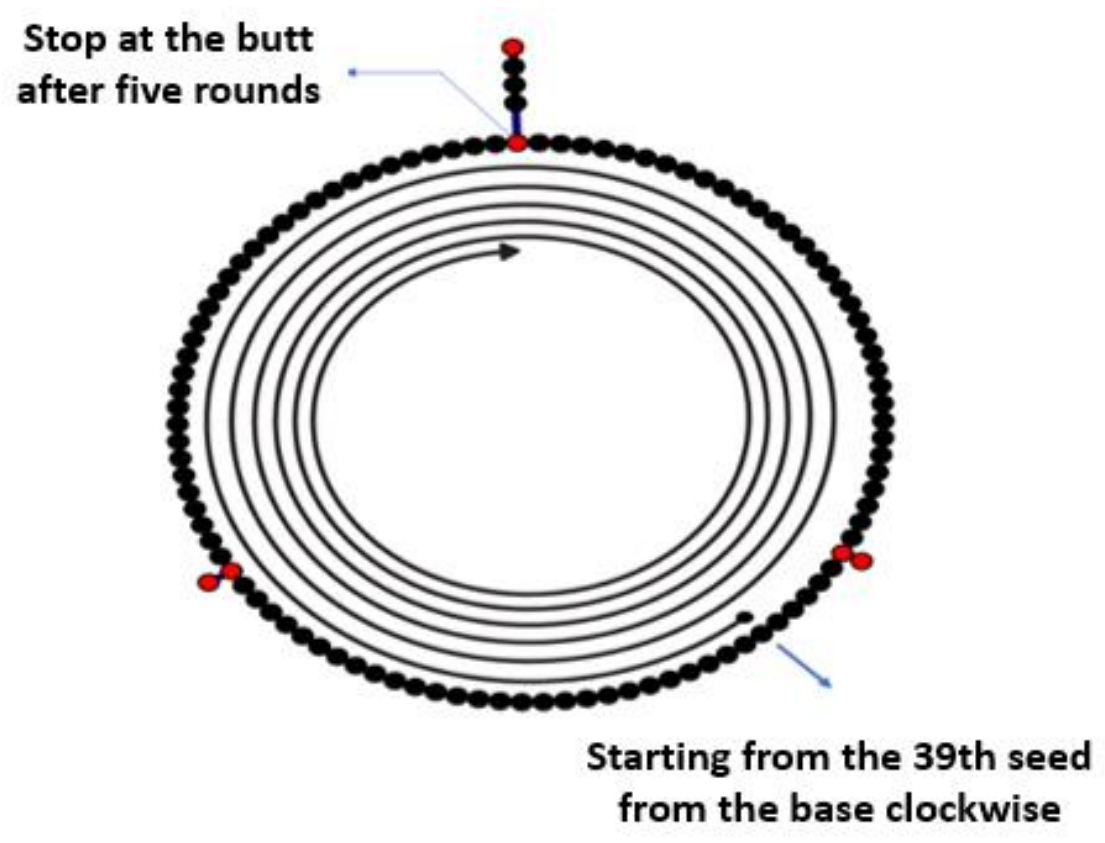

Figure 16. Mathematical Model of 561 Dhikr Type A

The Ikhwan made the sign number 61 by utilizing 2 prayer beads totaling 66 minus 5 seeds or if from the right (in Figure 10) it would start at the 39th seed or we write it as

$$
\begin{gathered}
(66-5)+5 \times 100 \\
=61+500
\end{gathered}
$$




$$
=561
$$

The second concept is (always) to start the dhikr from the base of the tasbih. There is no special reason for Ikhwan who always start dhikr with tasbih from the root of the seed, except for the reason that they are "habitual / comfortable" that starting from the root.

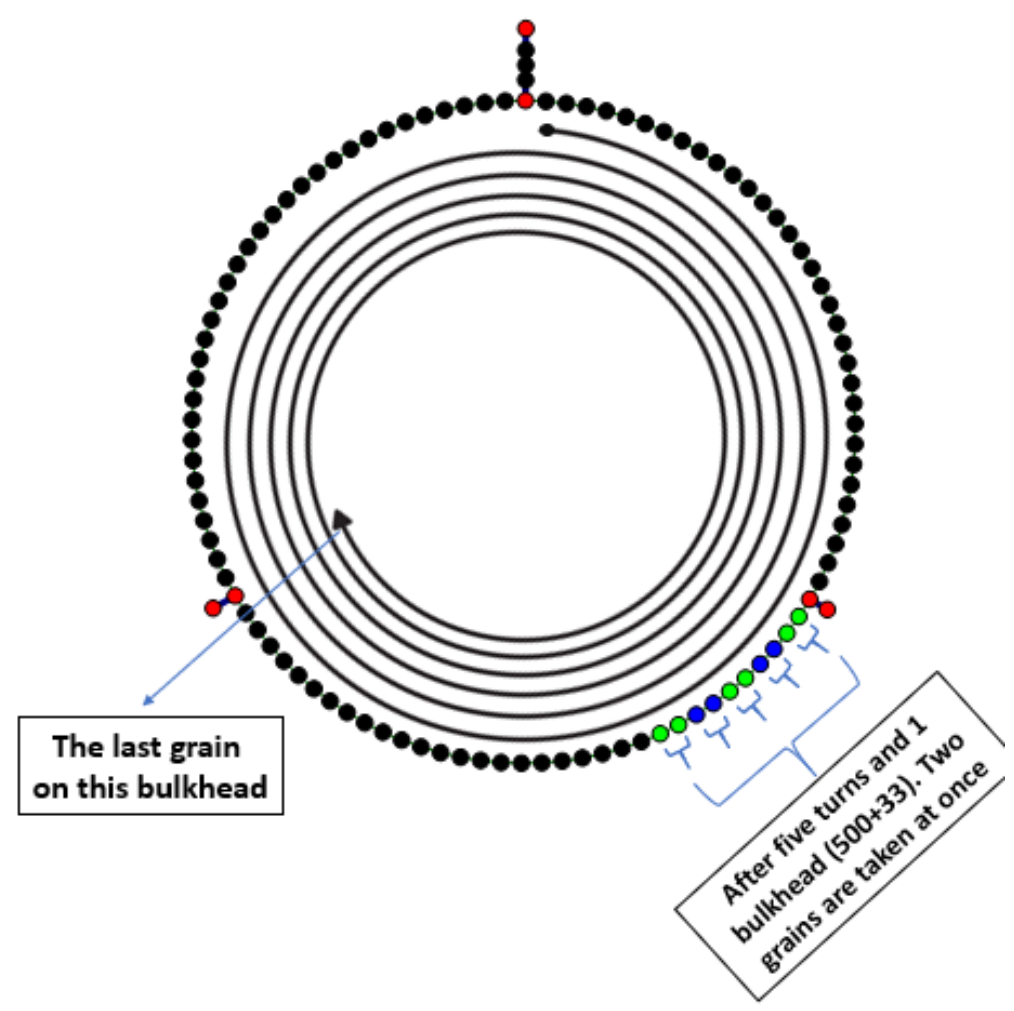

Figure 4.17 Mathematical Model of 561 Dhikr Type B

Recitation starts from the first seed from the base for 5 rounds and then continues until the first partition. Every 1 dhikr moves 1 tasbih but after 5 rounds (500) and 1 bulkhead (33) then there are 5 tasbih picks where once take 2 seeds directly. Mathematically it can be written:

$$
\begin{gathered}
5 \times 100+33+(2-1)+(2-1)+(2-1)+(2-1)+(2-1)+23 \\
=500+33+(1 \times 5)+23 \\
=533+28 \\
=561
\end{gathered}
$$

or in the other words the concept of $33+(1 \times 5)+23$ by the Ikhwan is another model of calculation (66-5) which can also be written as

$$
\begin{aligned}
500 & +(66-5) \\
& =561
\end{aligned}
$$

- The Concept of Counting 2500 Dhikr

Researchers found one respondent who used the number 2500 as a mainstay of dhikr. This dhikr is done by respondents outside the daily dhikr, namely at midnight during the Tahajud prayer. He uses a simple counting concept by using two prayer beads at the same time (one in the right hand to count units, one in the left hand for hundreds of markers). 

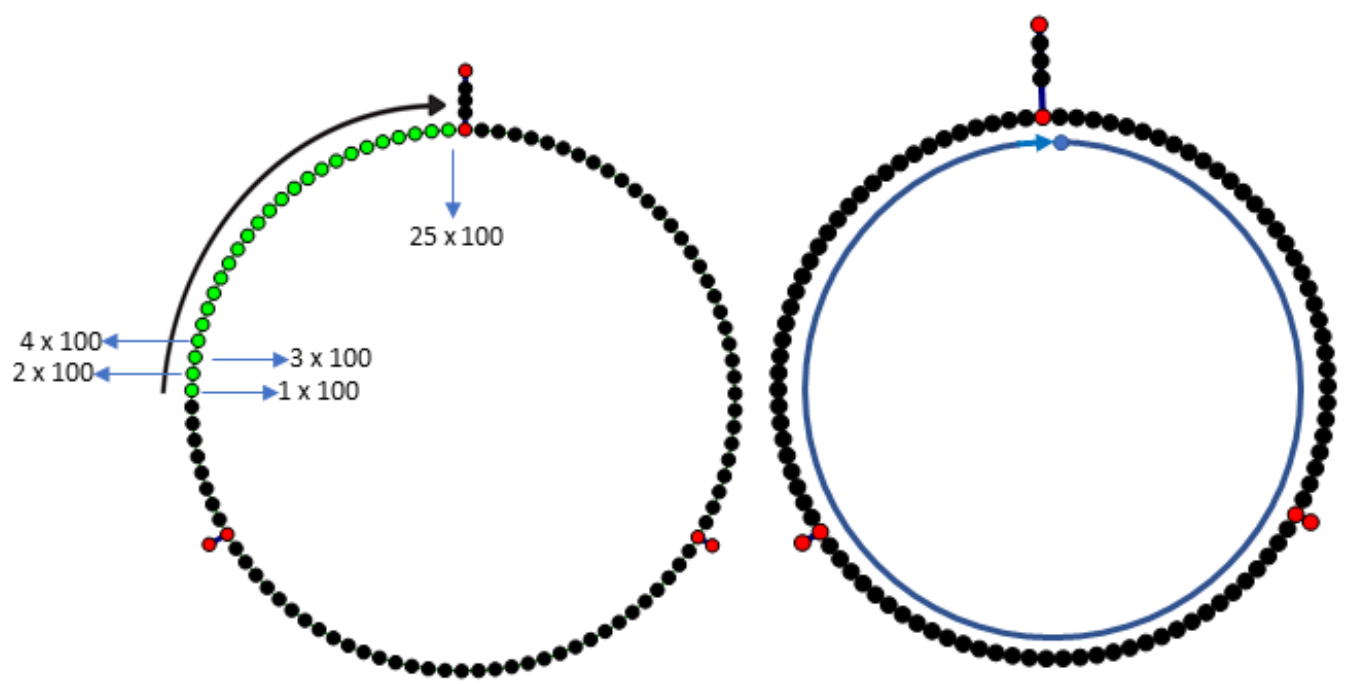

Figure 18. Mathematical Model of 2500 Dhikr

The concept of counting 2500 with 2 tasbih is done by marking 1 tasbih on the left as 100 Dhikr on the right tasbih. The Ikhwan first marked 25 beads on the left so that the deadline for dhikr was at the base of the tasbih. Very simply this can be written as 25 x $100=2500$.

From the above explanation, we can now distinguish more clearly between mathematical phenomena and mathematical concepts. Mathematical phenomena are constructed with an ethical approach by people outside the subject of observation (indigenous), in the context of research they can be researchers, experts, or even authors and reference books. Mathematical concepts can be expressed using techniques similar to mathematical phenomena, it's just that what is revealed must be a way of thinking or indigenous consciousness itself. In a practical sense, the way of thinking written by the researcher describes an indigenous way of thinking. Meanwhile, mathematical phenomena are free from it, or it can be purely an observer's interpretation outside the indigenous.

The discovery in this research have complemented the mathematical phenomena revealed by the authors in the previous paper (Yulianto et al., 2020). In the previous paper, only mathematical phenomena were disclosed and had not been compared with mathematical concepts. The discovery in this research by contrast distinguish mathematical concepts from mathematical phenomena. The mathematical concept describes mental entities which are consciously applied by indigenous in daily practice of dhikr. In other words, this is expressed by the emic method (Orey \& Rosa, 2015). Mathematical knowledge can be seen to emerge from emic rather than ethical origins (Eglash et al., 2006). This mathematical idea was poured out by the researcher but based on indigenous original thoughts, not by the researcher. This process of translating is called ethno-modeling (Orey \& Rosa, 2015). In other words, efforts to express mathematical ideas using the emic method have been initiated by ethnomathematics researchers.

This kind of discussion style (contrasting phenomena and mathematical concepts) can be an alternative in ethnomathematics research. Increasing mathematical concepts rather than mathematical phenomena can strengthen the existence of ethnomathematics research and answer the accusation that "ethnomathematics is only a mathematical incidental (Indonesian: Cocokologi) research conducted by researchers". Cocokologi is the science that matches one 
thing to another in the form of arguments that are forced to fit (Silalahi et al., 2020). The term Cocokologi comes from language games. One of the language games to argue in the discourse of Cocokologi is to take advantage of the spelling aspect related to the symbolization of the sound of language in written form. This aspect relates to the use of letters. In a broader context this can happen in mathematics and religion.

One of the mathematical phenomena that can be called Cocokologi includes the belief that some people have unlucky numbers. In cultures that believe in numerology, numbers are believed to have an influence on human life. In ancient times, the Greeks believed certain numbers had magical powers. Then the mythology of figures for the Romans and English people that,

The Romans had a myth that breaking a mirror would bring bad luck and it took the human body seven years to renew itself after the mirror was broken ... and the taboo number 13 was for the British as an unlucky number that led to the history of Jesus' death. At the last supper, Jesus gathered 12 of his followers for a special meal, but, including him, there were a total of 13 at the table. Therefore, the number is associated with the traitor, Judas, Jesus' thirteenth disciple (p.516-517).

In Babylon the numbers 1 to 60 were associated with various Gods. This doctrine has been started since the time of Pythagoras (550 BC) which was written in a major work entitled All is Number to form a sizable religious sect and its worship practices that seem to involve substantially mathematics. Even the historian of mathematics, Carl B. Boyer, wrote 'never before or since mathematics played such a role in life and religion as it did among the Pythagoreans (p.7)'. This means that there was a time when mathematics became part of the theological approach.

The mathematical phenomena revealed by the author are very likely to be said to be a Cocokologi by anyone. This is due to the difficulty of validating the epistemological truth of these discoveries. Apart from being exposed to these mathematical phenomena in an ethical way, of course we need a lot of data to explain the origin of this phenomenon or if necessary, evidence of these phenomena has an impact on human life. Therefore, it is fitting that the epistemology of the process of disclosing phenomena in ethnomathematics is questionable. With this idea, the author tried to contrast the concept of mathematics as a distinct from mathematical phenomena. The original mathematical concept shows the thinking process of the indigenous which is proved that the concept has really benefited a certain group of people.

\section{CONCLUSIONS}

The results showed that there are many mathematical phenomena in the practice of Dhikr Jahar Ikhwan TQN. In carrying out the practice of dhikr, the Ikhwan used a mathematical concept with two events, fingers and prayer beads aids. The concept of counting in dhikr was used strictly by the Ikhwan. They believe that numbers have an important role in the quantity of dhikr. Contrasting mathematical phenomena and mathematical concepts can be done with an emic and etic approach and is expected to become an alternative style in ethnomathematics research. Increasing mathematical concepts rather than mathematical phenomena can 
strengthen the existence of ethnomathematics research and answer the accusation that "ethnomathematics is only a mathematical incidental research conducted by researchers".

This explanation is expected to strengthen the understanding that mathematics and religion are two things that are not dichotomous. The discovery written by the author shows that there is a side where mathematical concepts are needed in carrying out religious rituals. From a more philosophical meaning, this also shows that mathematics is present in a wider and more flexible way in the order of human life, it means that mathematics is not as rigid as formal mathematics in schools. From the educational aspect, this ethno-mathematical content can be included in the curriculum as part of the content that introduces various local wisdoms. Through this paper, the author has attempted to compare mathematical phenomena and mathematical concepts in contrast in order to provide a sharper spotlight in the writing of ethnomathematics research. Perhaps this could be adopted by future researchers.

This research has limitations. Author hope there will be further researches that explore the axiological aspects of the practice of Dhikr in Tariqa which are known to involve mathematics very closely. One of the further researches needed to continue this research is a phenomenological research of the impact of Dhikr which is carried out in a certain amount.

\section{ACKNOWLEDGEMENT}

The author would like to say thank and much appreciation to Universitas Siliwangi, as the Home Base for the authors' work, Indonesia Endowment Fund for Education (LPDP) and the directorate of Indonesia Higher Education who supported the author's scholarship program and funding for doctoral program at Universitas Pendidikan Indonesia.

\section{AUTHOR CONTRIBUTIONS STATEMENT}

EY and WW worked as the main drafter in this research. data collection and instrument design assisted by AT and SP.

\section{REFERENCES}

Abdussakir. (2014). Matematika dalam Alquran. Malang: UIN-Maliki Press.

Adawiyah, R. (2015). Yasin dan Ismul A'dzam (Nama Allah Yang Teragung).

bin Ahmad Al-Farahidi, A. K. (1985). Kitab al-Jumal fi al-nahwi. Muassasah al-Risalah.

Alviani, H. (2017). Implementasi ajaran tarekat qadiriyah wa naqsyabandiyah dalam kehidupan sosial masyarakat (Studi di desa Depok Rejo Kecamatan Trimurjo Kabupaten Lampung Tengah). Universitas Islam Negeri Raden Intan.

Amin, S. M., \& Haryanto. (2008). Energi zikir. Jakarta: Amzah.

Anugrah, R. L., Asrin, A., Musa, F., \& Tanjung, A. (2019). Islam, iman dan ihsan dalam kitab matan arba'in an-nawawi (studi materi pembelajaran pendidikan islam dalam perspektif hadis Nabi SAW). Tarbiyah: Jurnal Ilmiah Pendidikan Agama Islam, 9(2), 29-44.

Awan, N. M. (2009). Quran and Mathematics-I. Jihāt Al-Islām, 3, 39-59.

Azharini, E., \& Nency. (2019). Metode Penelitian Kualitatif - Fenomenologi. Sekolah Tinggi Agama Islam Sorong.

Bahri, S. (2019). Fiqh konseling: Pertautan trilogi antara iman, islam dan ihsan (ti3) dalam 
menjawab kegelisahan akademik dan problematika pendidikan. La-Tahzan: Jurnal Pendidikan Islam, 11(1), 37-51.

Basri, T., Badaruddin, F., \& Mohamad, A. M. (2014). Konsep zikir darajah dalam disiplin ilmu tarekat. Jurnal Islam Dan Masyarakat Kontemporari, 8(1), 61-72.

Basya, F. (2009). Matematika Islam 3 (2nd ed.). Jakarta: Republika.

Basya, F. (2015). Jelajah Indonesia Negeri Saba’ (1 st ed.). Jakarta: Zahira.

Creswell, J. W. (2007). Chapter 3: Designing a qualitative study. Qualitative Inquiry and Research Design: Choosing among Five Approaches, 35-41.

D’Ambrosio, U. (1990). Ethnomathematics. Sao Paulo: Edotora Atica.

D'Ambrosio, U. (1998). Ethnomathematics and its first international congress. ZDM, 31(2), $50-53$.

D'Ambrosio, U., \& D'Ambrosio, B. S. (2013). The role of ethnomathematics in curricular leadership in mathematics education. Journal of Mathematics Education at Teachers College, 4(1), 19-25.

Eglash, R., Bennett, A., O’Donnell, C., Jennings, S., \& Cintorino, M. (2006). Culturally situated design tools: Ethnocomputing from field site to classroom. American anthropologist. Anthropology and Education, 108(2), 347-362.

El-Bantani, M. S. (2010). Quantum islam, iman dan ihsan (Bentuk aplikasi syariat dalam berkehidupan). Jakarta: Inti Medina.

El Mouatasim, A. (2018). Simple and multi linear regression model of verbs in Quran. American Journal of Computational Mathematics, 08(01), 68-77.

Etikan, I., Musa, S. A., \& Alkassim, R. S. (2016). Comparison of convenience sampling and purposive sampling comparison of convenience sampling and purposive sampling. American Journal of Theoretical and Applied Statistics, 5(1), 1-5.

Godina, H., \& Rachelle, M. (2000). Emic and etic perspectives on Chicana and Chicano multicultural literature. Journal of Adolescent \& Adult Literacy, 44(2), 172-179.

Hajaroh, M. (2010). Paradigma, pendekatan dan metode penelitian fenomenologi. Jurnal Ilmiah FIP Universitas Negeri Yogyakarta, 1-21.

Halal, R., Aji, S., Masruri, H. M. H., \& Rossidy, I. (2014). Khazanah sains dan matematika dalam islam. Salam: Jurnal Filsafat Dan Budaya Hukum, 1(1), 155-168.

Hoare, K. J., Buetow, S., Mills, J., \& Francis, K. (2013). Using an emic and etic ethnographic technique in a grounded theory study of information use by practice nurses in New Zealand. Journal of Research in Nursing, 18(8), 720-731.

Kafie, J. (1981). Tuntuna pelaksanaan rukun iman islam dan ihsan. Surabaya: Al-Ikhlas.

Kamali, M. H., Bakar, O., Batchelor, D. A. F., \& Hashim, R. (2016). Islamic perspectives on science and technology. Springer Singapore.

Kurniawan, S., \& Tijani. (2017). Filsafat ilmu: Merajut harmonisasi antara filsafat, ilmu dan islam. Pontianak: IAIN Pontianak Press. 
Le Gall, Di. (2005). A culture of sufism: Naqshbandis in the ottoman world, 1450-1700. New York: Suny Press.

Linnaja, N. (2018). Internalisasi nilai-nilai pendidikan karakter dalam ajaran tarekat qadiriyah wa naqsyabandiyah di pondok pesantren an-nawawi berjan Purworejo. Jurnal Paramurobi, 1(2), 53-64.

Mahmudi, A. (2018). Al-Asma Al-Husna menurut thabathaba'i dalam tafsir Al-Mizan. UIN Walisongo Semarang.

Majid, N. (1995). Islam, iman dan ihsan sebagai trilogi ajaran ilahi. Jakarta: Mizan.

Manshur, S. M. (1925). Sulamun nayyirain. Jakarta.

Masood, E. (2009). Science and islam: A history. Pharmaceutical Journal (Vol. 272). United Kingdom: ICON BOOKS.

Murota, S., \& Chittick, W. C. (1997). Trilogi islam: Islam, iman, dan ihsan (1st ed.). Yogyakarta: Raja Grafindo Persada.

Muslim, I. (1992). Shahih muslim (Jilid V). Beirut: Darul Fikr.

Nindito, S. (2005). Fenomenologi alfred schutz: Studi tentang konstruksi makna dan realitas dalam ilmu sosial. Jurnal Ilmu Komunikasi, 2(1), 79-95.

Noegroho, I. R. (2019). Dasar-dasar memahami iman, islam, dan ihsan. Yogyakarta: Mueeza.

Nurhasanah, S. (2015). Implementasi metode zikir untuk meningkatkan self-esteem (harga diri) remaja di pondok pesantren Suryalaya, Tasikmalaya, Jawa Barat.

Orey, D. C., \& Rosa, M. (2015). Three approaches in the research field of eethnomodeling: emic (local), etic (global), and dialogical (glocal). Revista Latinoamericana de Etnomatemática, 8(2), 364-380.

Pierce, C. S. (1998). The essential Peirce. In The Peirce Edition Project. (C.S. Pierce,Ed.) (Vol. 2). Bloomington: Indiana University Press.

Pike, K. L. (1967). Language in relation to a unified theory of the structures of human Behavior (2nd Ed.). The Hague, Netherlands: Mouton.

Qosim, M. N. (2016). Unsur-unsur lingual dalam wacana wifiq. Jurnal Al-Tsaqafa, 13(1).

Quddus, A. (2007). Islam multidimensi: Mengungkap trilogi ajaran islam. (F. Dahlan,Ed.) (1st ed.). Mataram: Pantheon Media Pressindo.

Rathony, M. A. (1972). Tiga serangkai sendi agama: Tauhid, fiqih tasawuf. Bandung: Alma'arif.

Rozak, L. A. (2015). Sejarah matematika didunia islam. In E. Yulianto (Ed.), Karya Mahasiswa Teori Bilangan (Vol. 1, pp. 186-190). Tasikmalaya: Universitas Siliwangi.

Shulthoni, M. (2011). Bisnis dan tarekat: Studi tentang kegiatan bisnis komunitas tarekat naqsyabandiyah Khalidiyah, Sokaraja, Banyumas, Jawa Tengah.

Silalahi, M. C. P., Sudarsono, S. C., \& Wardani, M. M. S. (2020). Permainan bahasa dalam wacana cocokologi pada acara "Ini Talk Show" di NET. Jurnal Ilmiah Kebudayaan 
Sintesis, 14(1), 94-108.

Sobur, A. (2014). Filsafat komunikasi (tradisi dan metode fenomenologi). Bandung: PT Remaja Rosdakarya.

Soleha. (2015). Makna hidup bagi pengikut tarekat qadiriyah wa naqsyabandiyah di Sukamara Kalimantan Tengah. Teologia, 26(2), 323-346.

Syed Abdurrahman. (1998). Kepentingan zikir dalam mendidik rohani dan jasmani pendakwah. Jurnal Usuluddin, 8(11), 135-144.

Ta’jul Arifin, A. S. (1998). Kunci pembuka dada. Batu Caves: Thinker’s Library.

Ta'jul Arifin, A. S. (2009). Kitab uquudul jumaan (3rd ed.). Tasikmalaya: PT. Mudawwamah Warohmah.

Tripp-Reimer, T. (1984). Reconceptualizing the construct of health: Integrating emic and etic perspectives.

Wahyudi, A. (2014). Islam, Iman, dan Ihsan.

Yulianto, E., Wahyudin, Prabawanto, S., \& Tafsir, A. (2020). Some ethnomathematics interpretations about the practice of dhikr jahar of tariqa qodiriyah naqsyabandiyah ma'had Suryalaya. Journal of Physics: Conference Series, 1477(042032), 1-12.

Zidni, I. (2015). Syarah uquudul jumaan. (S.M. Abdul Gaos,Ed.). Jakarta: Sufi TQN. 